This item was submitted to Loughborough's Research Repository by the author.

Items in Figshare are protected by copyright, with all rights reserved, unless otherwise indicated.

\title{
Using capital theory to explore problem solving and innovation in small firms
}

PLEASE CITE THE PUBLISHED VERSION

http://dx.doi.org/10.1108/JSBED-02-2014-0033

\section{PUBLISHER}

Emerald

\section{VERSION}

AM (Accepted Manuscript)

\section{PUBLISHER STATEMENT}

This work is made available according to the conditions of the Creative Commons Attribution-NonCommercialNoDerivatives 4.0 International (CC BY-NC-ND 4.0) licence. Full details of this licence are available at: https://creativecommons.org/licenses/by-nc-nd/4.0/

\section{LICENCE}

CC BY-NC-ND 4.0

\section{REPOSITORY RECORD}

Champion, Donna, Jane Glover, Kevin Daniels, and Grahame Boocock. 2019. “Using Capital Theory to Explore Problem Solving and Innovation in Small Firms". figshare. https://hdl.handle.net/2134/19116. 
Using capital theory to explore problem solving and innovation in small firms

Using capital theory to explore problem solving and innovation in small firms

Keywords: problem solving, innovation, social capital, cultural capital, capital relationships, small enterprises. 
Using capital theory to explore problem solving and innovation in small firms

Using capital theory to explore problem solving and innovation in small firms

\section{Purpose}

This study investigated how small firms work at a micro-level, applying Bourdieu's Capital Theory to give insight into the way individuals use the social and cultural capital at their disposal, to innovate and solve problems.

\section{Design/Methodology/Approach}

We applied qualitative methods to explore problem solving and innovation activities at the micro-level in small firms, using interviews and thematic analysis.

\section{Findings}

Our findings reveal that, compared to firms with lower levels of social and cultural capital, firms which possess higher levels of social and cultural capital have a higher success rate in problem solving and are more likely to engage in innovative activity. Social and cultural capitals complement and reinforce one another in small firms, for example an enhanced ability to utilise networks (social capital) allows small firms to access a greater diversity of knowledge (cultural capital).

\section{Originality/Value}

Little is known about how different forms of capital are utilised in the day-to-day operations and problem solving of small firms: the application of Bourdieu's Capital Theory offered an original frame in which to explore these activities.

Keywords: Problem solving, innovation, social capital, cultural capital, capital relationships.

\section{Introduction}

Small firms, defined by the EU as those with fewer than 50 employees whose balance sheet size or annual turnover does not exceed 10m euros (European Union, 2014), often encounter problems that stem from changes and uncertainty in the external environment; and each small firm will respond in different ways to those challenges (Levinthal, 2000; McMullen and Shepherd, 2006) by drawing upon a mix of resources (or capitals in the terminology to be used in this paper). 


\section{Using capital theory to explore problem solving and innovation in small firms}

Within the literature, this type of behaviour has most often been explained in terms of a resource-based view (RBV) of a firm (Wernerfelt, 1984; Barney, 1991). RBV views competition between firms as being explained by companies possessing heterogeneously distributed resources that are valuable, rare, inimitable and non-substitutable (the 'VRIN' characteristics). Individual firms within groups that might have been viewed as homogeneous, such as 'the small firm sector', are seen to possess a combination of difficultto-imitate resources which accounts for variability in their financial and operational performance compared to their counterparts (Ray et al., 2003; McMullen and Shepherd, 2006). But RBV theory has been criticised for having a narrow conceptualisation of resource and value, and so of a firm's competitive advantage. For example, Storey and Green (2010) criticise RBV on its inability to explain how firms alter the combination of VRIN attributes to sustain competitive advantage over time.

Problem solving is often a precursor to innovation, yet a small firm's capacity to solve problems is often hampered by a lack of resources from the external environment (Grande et al., 2011); such restrictions can have severe implications for small firms, as innovation constitutes a critical source of their advantage (Scott and Bruce, 1994; Lundvall, 1992; Lundvall and Nielsen, 2005). In their efforts to overcome a lack of resources, small firms have explored different ways in which to create, capture and supplement internal capitals (human, social, cultural capital and so on). For example, Gibson (1991, pp. 117-118, cited in Conway and Jones, 2012, p. 338) suggests that "the more extensive, complex and diverse the web of relationships, the more the entrepreneur is likely to have access to opportunities, the greater the chance of solving problems expeditiously and, ultimately, the greater the chance of success for a new venture”. In this paper, we suggest that these activities would be more usefully explored through Bourdieu’s Capital Theory (Bourdieu, 1984, 1986, 1998), where webs of relationships are seen as a critical component of social capital.

Many studies have explored innovation in small firms (including: Freel, 2000; Kalantaridis and Pheby, 1999; Motwani et al., 1999; Vossen, 1999; Romero, 2011), but these studies have tended to focus on the outcomes (or outputs) of innovation on individual firms or the wider economy. The exploration of the processes (or inputs) that influence innovation in small firms has been a neglected area; Crossan and Apaydin (2010) argue strongly for research studies that conduct micro-level analysis of the innovation process within small firms because (p.1179): “it is at this 'micro level’ that the managerial reality enfolds every day, therefore a theory of innovation needs to connect the action (praxis) with the managerial 


\section{Using capital theory to explore problem solving and innovation in small firms}

and academic theories (practice) by understanding the role of agents (practitioners)". Microlevel analysis can thus provide a detailed account of how SMEs solve problems and/or innovate, and the aggregation of findings from multiple firms can enhance our understanding of macro-level outcomes.

In addressing the gap in knowledge identified by Crossan and Apaydin (2010), this study draws upon the seminal thinking of Pierre Bourdieu to explore, from a capital theory perspective, problem solving and innovation in the SME context. The influence of Bourdieu is evident in the literature on entrepreneurship and innovation (De Carolis and Saparito, 2006; De Clercq and Voronov, 2009), for example: there has been growing interest in the role of social capital in new venture creation (De Carolis and Saparito, 2006; De Carolis et al., 2009) and also its role in entrepreneurship (Baron and Markman, 2005; Wright et al., 2008; Aarstad et al., 2010).

Capital theory is still emerging as a research field, yet it can unlock key questions; we recognise the contribution of the RBV, but suggest that capital theory offers the opportunity for a more nuanced examination of the types of resources available to small firms and the interactions between those different forms of capital. We echo calls for studies that exploit the theoretical and empirical base of the work of Bourdieu and others to analyse the ways in which organizations evolve (Emirbayer and Johnson, 2008; Vaughan, 2008). In particular, little is known about how different forms of capital are utilised in the day-to-day operations of small firms and hence daily problem solving. This paper is one of the first to focus on the role of valuable resources (specifically social and cultural capital) in solving problems and implementing appropriate solutions in SMEs, although recent work has explored the level of problem-solving skills in SMEs (Giroux, 2009). By focusing on the utilisation of capitals for problem solving and innovation, we argue that this study makes an important contribution to the literature on SMEs, resource management and innovation.

In the next section, we introduce capital theory and explain its relevance and unique insight into how small firms are enabled to grow and succeed; we then review the literature on innovation and problem solving before detailing our research methodology. We then discuss our findings before drawing some conclusions on the relationship between social and cultural capital, and the potential applicability of capital theory to this field. 


\section{Using capital theory to explore problem solving and innovation in small firms}

\section{Capital Theory}

Bourdieu is concerned with what people do in their daily lives (Jenkins, 1992). This premise is a key rationale for choosing his body of work for micro-level analysis of how individuals in small firms innovate and solve problems. Bourdieu's main theoretical contribution has been to develop the concepts of 'field', 'habitus' and 'capital' (Bourdieu, 1990). Field and habitus are defined briefly below, before Bourdieu's key concepts of capital are introduced.

Field refers to a social space in which players are positioned with given resources. For the individual player, habitus refers to a combination of perception, thinking, feeling, evaluating, speaking and acting. Habitus pre-formats the actions of individuals without predetermining them (Bourdieu, 1991, 1998). The field provides a structure (and rules of the game) where actions enable players to gain control over resources. Bourdieu classifies the resources available to individuals or firms into capitals, and he identifies four different forms of capital; in the context of the farming industry (a key element of our study), these comprise (1984, p. 14): economic capital in the strict sense (material wealth in the form of money, stocks and shares, property - farmhouse, buildings, land, animals, machinery and so on); cultural capital (knowledge, skills and other cultural acquisitions as exemplified by educational or technical qualifications); social capital (actual or potential resources from social networks, such as hubs, discussion groups, industry groups, innovation centres); and symbolic capital (accumulated prestige or honour).

Bourdieu considers all forms of capital to be mainly in the hands of dominant classes, who occupy pinnacle positions in society (Lin, 2001). Capital can accumulate over time, and it has the potential to produce profits and reproduce itself in identical or expanded forms; conversely, it can also decline. Bourdieu's approach is based on the view that actors are engaged in a struggle in order to achieve their aims (Bourdieu, 1986). We agree with Corti and Storto (2000), and Perez and Sanchez (2002), that cultural and social capital are the most important resources employed by SMEs in solving daily work problems; further, we suggest that Bourdieu's conceptualisation of these capitals can be applied to give insight into problem solving and innovation activity in SMEs. Bourdieu's ideas on social capital have been applied to larger networks involving nation states, but Portes (2000) cautions against stretching the heuristic that far. We have focused on the networks available to small firms.

From different perspectives and starting points, Bourdieu and others, including Coleman (1988) and Putnam (1993), agree that social capital consists of resources embedded in social relations and social structures; these resources are then accessed or mobilised in 


\section{Using capital theory to explore problem solving and innovation in small firms}

purposive actions (Schuller, Baron and Field, 2000; Field, 2003). Likewise, it is accepted that social capital is an investment to increase the likelihood of expected returns (Lin, 2001), and it can be secured by individuals and organizations (Furstenberg, 2005). The interaction of such ideas culminated in this formal definition of social capital by Bourdieu (1998, p. 51): “... the aggregate of the actual or potential resources, which are linked to possession of a durable network of more or less institutionalised relationships of mutual acquaintance and recognition .... [providing] each of its members with the backing of collectively-owned capital”.

Some social ties (networks), resulting from their strategic locations and positions (status), carry more valued resources and exercise greater power on organizational agents' decision making (Clarke, 2000; Lin, 2001). Networks, both personal and business, can have a critical impact upon the small firm (Vissa and Bhagavatula, 2012), mainly by providing access to knowledge outside the firm and offering mechanisms through which small firms accumulate and distribute knowledge (Cohen and Levinthal, 1990). The level of knowledge generated by this process, either directly or indirectly ('spilled over'), depends on whether the network ties are strong or weak (Clarke, 2000; Granovetter, 1985; Lin, 2001) and also on the density of relationships available (Yli-Renko et al., 2001; Koschatzky, 1998).

Bourdieu claims that the distribution of social capital is inherently uneven. The volume of social capital possessed by an individual depends on the size of network connections s/he can effectively mobilise, and on the volume of capital (economic, cultural or symbolic) possessed by each of those individuals or groups to whom $\mathrm{s} /$ he is connected (Bourdieu, 1983, 1986). Increased networks of relationships, reciprocity and levels of trust act as viable mechanisms to enhance levels of social capital (Lin, 2001). Furthermore, those who have the most valuable connections are liable to use those networks to advance their own interests, thereby causing further inequality (Field, 2003). Thus, powerful groups can limit or undermine the social capital of those who are less powerful (Schulman and Anderson, 1999; Field, 2003). Those groups that possess relatively high levels of economic and cultural capital also tend to have high levels of social capital (Field, 2003).

The notion of cultural capital is now explored further. According to Bourdieu, cultural capital can exist in three forms: long-lasting dispositions, such as mannerisms learned from family or gained from personal experiences; cultural objects - pictures, books, instruments and so on, as well as exposure to such objects through (say) visiting museums, art galleries and theatres; and, capital acquired from institutions, for instance educational or 


\section{Using capital theory to explore problem solving and innovation in small firms}

professional qualifications (Bourdieu, 1977, 1984, 1986). In essence, Bourdieu sees cultural capital as knowledge, expertise and experience embodied in individuals and derived from their social origins (Bourdieu, 1986, 1991). Within the literature, the concept of human capital has been relatively neglected. However, there was a clear intention on the part of Bourdieu to extend the boundaries of human capital beyond (say) conscious decisions by individuals to enhance their education and training. Indeed, this widening of scope in cultural capital has been described as Bourdieu's key contribution to academic literature (Schuller, Baron and Field, 2000).

We discuss below how Bourdieu can enhance our understanding of the literature on innovation and problem solving; we contend that very few studies have examined problem solving as a driver of innovation, or acknowledged the value of capital theory in this context.

\section{Innovation and Problem Solving}

We follow a broad definition of innovation as: "any idea, practice, or product that is perceived as new by the potential unit of adoption” (Zaltman et al., 1973, p. 50). We argued earlier that small firms have to be innovative, because their limited resources leave them vulnerable to uncertainty, turbulence in business environments, the power of customers and suppliers, and so on (Motwani et al., 1999). Shortages of skills, the lack of any accepted system for measuring the success of innovation, weaknesses in external information and linkages, and difficulties in coping with government regulations also restrict the ability of small firms to compete with their larger counterparts (Buijs, 1987; Findlay et al., 2000; Freel, 2000; Rothwell, 1994). The prudent allocation of scarce managerial resources to support innovation is therefore critical (Vossen, 1999). In addition, entrepreneurial small firms seeking to exploit opportunities rely not only on their own resources, but also on resources owned by others (Ireland et al., 2003; Audretsch et al., 2009). This factor strengthens the case for using Bourdieu's work, as a key element of his contribution is the extent and distribution of power in a particular field.

As stated earlier, problem solving is an important first step in increasing the level of innovative activity in organizations (Lundvall, 1992; Scott and Bruce, 1994; Lundvall and Nielsen, 2005) and the ability to solve problems is also associated with enhanced learning and knowledge accumulation in organizations (Daniels et al., 2008; Champion and Wilson, 2010). Small firms that have taken an active role in searching for, and then integrating, 


\section{Using capital theory to explore problem solving and innovation in small firms}

knowledge have secured competitive advantage (as revealed in, for example: Bruneel et al., 2010; Gray, 2002; Liao et al., 2008; and, Tolstoy and Agndal, 2010).

The problems faced by small firms might stem from the activities of competitors (Watts et al., 1998), a lack of expertise in specific functions such as marketing (Leach and Kenny, 2000), or from changing customer needs or expectations (Pavia, 1991). In responding to those problems, the solutions implemented by small firms: might involve changes to systems or processes (Kazanjian, 1988; Ghobadian et al., 2003); might require additional functional or specific technical knowledge (Boussouara and Deakins, 2000; Lichtenstein and Brush, 2001); and, could be tactical rather than strategic (Patton and Marlow, 2002).

Individuals within a firm are important sources of knowledge (cultural capital). However, if a lack of internal knowledge is identified, entrepreneurs or owner-managers will need to seek alternative sources of knowledge in a problem-search-resolution process (Kazanjian, 1988; Deakins et al., 2000), for example: Corti and Storto (2000) stressed the value of the wider business and social community in solving technical problems. These wider sources (suppliers, customers and so on) are important for small firms requiring access to networks for specific purposes, such as launching a new product in an overseas market (Perez and Sanchez, 2002). Small firms could also seek to accumulate capital by employing consultants or seeking advice from accountants (see von Hippel, 1994, for a detailed review of information and problem solving). Building knowledge capabilities can thus increase levels of innovation in small firms (Corti and Storto, 2000) and, per Bourdieu, small firms possessing higher levels of cultural capital than similar firms would be expected to be more innovative.

Social capital can also enhance cultural capital through collaborations and knowledge exchanges, such as joint R\&D activities, joint ventures or strategic alliances (Dodgson, 1993; Freeman and Hagedoorn, 1994). Small firms are better able to innovate and learn when they are part of co-operative networks, as the networking process and the management of externalities enable them to develop new skills, knowledge, abilities, products, processes and services (Mohannak, 2007).

\section{Methodology}

The data for the study were collected using qualitative methods, which are concerned with understanding individuals' perception of the world (Bell, 1993). Caley et al. (1992) state that 


\section{Using capital theory to explore problem solving and innovation in small firms}

qualitative methods are designed to discover what happens in 'real life', where there is a complex interplay between action and belief. We were interested in conducting in-depth analysis of the individualistic approaches whereby small firms use the capitals at their disposal. A qualitative approach, with an interpretive underpinning, was appropriate as there were no previous studies to guide us. Interviews were chosen as the data collection method as they offer a mechanism for collecting rich data from which to explore and evaluate a range of perspectives (Cassell and Symon, 1994; Huberman and Miles, 2002), and through which we could develop greater understanding of relatively unexplored issues (Yin, 2003). Theoretical sampling was utilised for firm selection, to facilitate the identification of conceptual patterns between social and cultural capital, and problem solving and innovation, and hence aid the inductive development of theory (Eisenhardt and Graebner, 2007).

In total, 40 small firms were investigated. Data were gathered from two sets of firms (Case Study 1 - CS1, and Case Study 2 - CS2); these two sets offered opportunities to compare the problem-solving processes implemented by what are traditionally seen as relatively conservative, 'low tech’ organizations (CS1) with a set of innovative, technology-oriented firms (CS2). The sample firms for CS1 were selected from a network of small businesses that had interacted with the first author during her $\mathrm{PhD}$, with some new contacts added through word-of-mouth introductions from the network formed in the course of the study. The sample firms for CS2 had been gathered independently for an East Midlands Development Agency (EMDA) funded project on problem solving. Most of this sample came from those who responded to a mailshot of EMDA funded companies, or through contacts obtained via University Enterprise Offices. The interviews, 52 in total, were not designed to assess the precise extent of innovation within the individual firms, rather to gain a deeper understanding of how different types of small firms make use of social and cultural capital to solve problems in their dynamic, day-to-day activities. The authors accept that the sample size is relatively small, but this research has been an exploration of whether Capital Theory can add value to this field and, as such, we argue this project is of sufficient rigour to usefully set the scene for larger studies.

\section{CS1: Traditional sectors}

This set of 20 firms comprises ten dairy farms (and one cheese maker), five construction firms, and five traditional food outlets i.e. shops and public houses. These firms are located predominantly in rural areas, and all operate in highly-regulated sectors. Within the 20 firms, 


\section{Using capital theory to explore problem solving and innovation in small firms}

28 interviews were conducted with the 'owner', family members and/or employees. The principal purpose of these interviews was to explore the type of problems encountered by these individuals in their daily working lives and to examine how they went about solving those problems. The interviews, all conducted by the first-named author, were recorded, transcribed and coded (again by the first-named author). The findings were then discussed with two other members of the research team, and a consensus achieved on the themes generated from data analysis. These three industries are traditionally seen as low-technology. Indeed, farms are often excluded from research into small firms, yet this industry is the main employer in rural areas, it is engaged in diversified activities (such as barn conversions for holiday cottages), and it supports local communities and amenities.

The firms under investigation are mainly family-run enterprises, providing employment for between two and four family members in each instance, with non-family employees usually in the minority. The firms generally operate as partnerships rather than limited companies, and they remain largely (though not exclusively) under the control of the founding family. The sample firms were located in mid-Staffordshire (a county in the West Midlands of England), some were close to urban conurbations, while others were more peripheral (i.e. more distant from towns or cities).

\section{CS2: Innovative firms}

These 20 firms operate in a range of sectors; located in or near urban areas, they have increased access to resources such as high-speed internet connections. They were all located within Leicestershire (a county in the East Midlands of England). Ten firms were established, five were nascent but had already demonstrated innovative activity, and five were recent, technology-oriented spin-outs from the three Universities in the county. Seven firms operated in the Information Technology (IT) sector, and two in the bio-medical sector; four firms were involved in manufacturing, while the remaining seven were professional service providers.

In each instance, interviews were conducted with the managing director (MD) or member of the senior management team; again, the main focus of the interviews was to explore the types of problem encountered and the mechanisms established to solve those problems. In total, 24 interviews were conducted. In view of the heterogeneity of the firms in CS2, the interviewees were also asked about the firm's culture, strategic environment, resources and so on; further evidence was obtained from other sources, such as published accounts and 


\section{Using capital theory to explore problem solving and innovation in small firms}

company websites. Each interview was conducted by one or two members of the research team; however, the first-named author coded all the transcriptions to ensure consistency of interpretation. As with CS1, the findings were discussed with two other members of the research team, and a consensus achieved on the key features of the company.

\section{Data Analysis}

After transcription, the first-named author read the transcripts to familiarise herself with the content. She then re-read the transcripts and made notes on factors that stood out. On the third read, she purposefully adopted a coding system that reflected Bourdieu's social and cultural capitals, for example: social capital included the following codes - social connections, networks and team-working. The data were therefore analysed using constant comparison and thematic analysis: "the process of constant comparison continually compares data to data, concept to data, concept to concept, and linking concepts back to the data” (Glaser, 1996, p. 98).

\section{Empirical Findings and Discussion}

Our findings are grouped around three key themes - social capital, cultural capital and the amplification effect. Under each theme, we discuss the importance of a specific capital (or combination of capitals) for problem solving and innovation in the sample firms.

\section{Theme One: Social Capital}

In CS1, networking emerged as a common way for small firm owners to seek solutions to problems, and to discuss possible changes in working practices. Problems in CS1 firms were generally concerned with 'low-tech' operational issues, and it was evident that these familybased firms tended to utilise social or business networks - usually reliable and trusted local connections. However, family networks were usually the first port of call to assist in solving problems. A farmer's son stated that: “I had a problem with a cow and didn’t know what to do with her so I asked my dad what we should do. I trust his judgement; he's been working with cows all his life, so I'd rather ask him than an outsider”. If the family could not help, then interviewees turned to their employees or network of neighbours and friends in the wider farming community; the following quote from a construction firm reveals how immediate problems are solved: 


\section{Using capital theory to explore problem solving and innovation in small firms}

"I was digging this hole and the typical nightmare is we hit a drain, so I look at the problem with my workers; we discuss it and find a solution and get on and fix it before we end up with a massive problem”.

Such networks were especially important for the more conservative firms in CS1 seeking answers to problems, but not necessarily engaging in innovative activity - unlike (say) the problems in launching a high-tech product experienced by some firms in CS2.

In making sense of regulations affecting the industry, farmers also utilise 'outer' social capital beyond their immediate local networks. (These sources also enhance cultural capital, a theme taken up later in the 'Amplification' Section.) Outer sources of advice could include the relevant unions (notably the National Farmers Union) or the relevant UK Government bodies. By way of illustration, a farmer's wife explained that: "If I have a problem with the Nitrate Vulnerable Zones regulation and I don't know what to do, I'll phone the Environment Agency”. Whilst the majority of small firm owners actively sought help through social capital, one (older) farmer would try to solve problems on his own by trial and error; his attitude was: "I like the satisfaction of solving problems myself and, if it takes a little longer, so be it”.

In CS2, solving problems with help from others was again commonplace, as participants engaged with government agencies, accountants and other professionals, other small firms and industry networks. One interviewee involved in web design summarised the position: "Networking is very important. You need to build up relationships, often to resolve specific problems”. Social capital is especially important for firms in specialist industries; a firm involved in promotional work and based on a university campus stressed that: "We network through the Innovation Centre and the University; it has helped us a lot”. Indeed, the MD of one small events management firm claimed that social capital had saved her company; without strong personal links to her previous employer in the same sector, the company would have folded shortly after starting:

"I was struggling to get work but I knew the firm I worked for before was busy so I went back there and said that, if they had too much work on, would they recommend me; or, if they were approached for small jobs they didn't want to do, would they pass them on to me? Luckily they said yes, as I had developed a good working relationship with the boss there and I left on good terms. They put quite a lot of work my way and I've been able to build up a client portfolio to showcase to potential clients. It saved the business really”. 


\section{Using capital theory to explore problem solving and innovation in small firms}

Networking is not all-encompassing; small firms operating in certain sectors preferred not to network with their peers, otherwise they might not retain their competitive advantage. This concern is cited in another context below.

In CS2, firms with lower levels of immediate problem solving (and hence less need for urgent innovation) tended to use fewer networks, than those experiencing high levels of problems in their day-to-day activities. Firms operating in specialist areas, and especially those with a record of successful problem solving, made more use of social capital. They networked through a variety of means, including conferences, the MD’s individual contacts, innovation centres, customers and suppliers. A greater reliance upon outer social capital networks was evident, with the caveat that small firms in the same sector or even in the wider small firm population were excluded. In the eyes on one service provider: "We network through the Innovation Centre to increase our customer base, but other small firms are not vital for us”.

In CS1, innovation was largely incremental, utilising the family network or employees to solve problems that arose in day-to-day operations. As one farmer explained: “If we can’t sort the problem out, then I'll ask my brothers; they both farm and we have similar businesses; for example, I was using too much water for washing down, so my brother told me about this piece of kit you could get to regulate water flow”.

Similarly, construction firms relied heavily on talking things through with other family members or the workforce to solve immediate daily problems; one construction firm owner described how:

"We arrived on site to [discover] a major drain issue; the side that had been dug out had collapsed after heavy rainfall in the night. It needed immediate resolution so we had to have a quickfire discussion to find a suitable solution before it created another problem”.

In CS2, spin-outs from universities or firms located in or near to Innovation Centres were more likely to have access to wider social networks and a greater diversity of contacts; in particular, the ability to engage with mentors or other small firms was enhanced.

In assessing the data in its entirety, there is evidence to support strongly the notion that higher levels of social capital facilitate increased levels of successful problem solving. In the farming community, for example, persistent, unresolved problems were present where social capital was not utilised; in the words of one farmer: "I have a number of problems at the moment but I can only manage one at a time myself”. It was also clear that key 


\section{Using capital theory to explore problem solving and innovation in small firms}

individuals in smaller enterprises tend to dip in and out of networks as necessary; the owner of a PR firm stated that: "I will go to events held by the Innovation Centre, but only if I think they will benefit the firm”.

Overall, our empirical data indicated that successful firms tend to utilise a variety of socially-based actions to solve problems. Our principal conclusion under this heading was that firms able to access and utilise networks from within or outside the organization were more successful in their problem-solving activities than those that could not. High-tech firms tended to seek specialist social capital outside the firm. Our findings lead us to propose that social capital is a pre-requisite for successful problem solving, rather than the prevailing view that problem-solving activity leads to increased levels of social capital.

We also propose that small firms located in more peripheral areas and operating in low-tech industries are more likely to use trusted inner social capital than those located in urban areas. Traditionally, this dependence might have been associated with an absence of technological infrastructure, but we contend nowadays that it stems from the relative lack of external networks in peripheral areas and also the distance from business gatherings and institutions such as universities and government support agencies.

In considering social capital as a whole, small firms were able to utilise a variety of networks in order to assist innovative activities. Our research supports the notion that successful problem solving and innovation originates not only from high levels of social capital acquired from networks specific to the firm involved, but also from high levels of social capital within the boundaries of the organization.

\section{Theme Two: Cultural Capital}

Cultural capital stems from educational qualifications, skills, personal experiences and cultural norms, including the possession of cultural items. Education aids understanding and raises the level of cultural capital possessed. However, the ability to draw upon a range of cultural and other capitals is often necessary, irrespective of the industry or sector in which a firm is located. For example, a farmer’s daughter stressed that: “The key to a successful farm is a business-minded person. You need to have a business mind as well as the technical knowledge to run this type of business".

Farms in more peripheral areas had to rely more on family skills and knowledge; they explained that it was difficult to attract skilled, non-family employees to these more remote farms without offering accommodation as part of the remuneration package (this was not 


\section{Using capital theory to explore problem solving and innovation in small firms}

always possible); over and above 'learning the business' from family members, farmers can enhance their cultural capital through experience and from external institutional sources. For example, one farmer put his experience to good use to solve a pressing problem:

"I had an immediate problem with one of the tractors; it was the weekend and I didn't want to call out the mechanic as it would be double time. So, in order to keep using it, I had to think creatively; it was leaking oil at the back and we couldn’t have oil running everywhere so I persuaded my wife to let me have a deep baking tray, drilled holes in it and fixed it to the tractor under the leak with string. I could then collect the oil, keep it clean and re-use it”.

Learning from family members was also evident in the construction firms, sometimes complemented by educational qualifications:

"I taught my son the basics of digger driving and then he went on a course and has completed all his qualifications”.

The value of networks for gathering information to solve problems was stressed earlier, but the owner of the largest farm in our study felt that it was more appropriate to increase his own level of awareness and knowledge: “If I want to know something, I don’t network; I'll read industry literature and find it out for myself'.

Yet, as a farmer's son explained, any amount of cultural capital might not be enough to combat unforeseeable problems:

“This winter we ran out of silage and had to turn out [our stock to pasture] early, but I was able to use some of my knowledge gained from working on grass-based systems in New Zealand to help us do this quicker”.

In CS2, some of the participants required ready access to a range of skills hence they employed people from a variety of backgrounds. A software developer located near a university had recruited skilled staff, and a representative commented that:

"Everyone has complementary skills and therefore people share skills. Ad hoc daily problems are solved in teams, or people discuss problems amongst themselves on a more informal basis. We're always using e-mail or the telephone, or meeting face-toface to solve problems, for example we are constructing a new educational disk and we were really struggling to get one part of the package right; so, we all sat down and went about solving the problem using our areas of expertise”. 


\section{Using capital theory to explore problem solving and innovation in small firms}

It was also apparent in CS2 that specialist firms tend to build up and renew cultural capital through in-house expertise. One manufacturer had drawn upon the knowledge and skills of its ageing workforce; the MD stated that:

"We have to train the people up on the job; even if they have a degree they are all trained on the job because we do things in a certain way here and people need to know how to do it that way to ensure the quality of the product”.

This was also the case for a recruitment firm where more experienced staff would train new recruits. The MD viewed this as a vital way to pass on valuable, company-specific knowledge that could not be acquired through qualifications.

Firms involved in cutting-edge research or those facing highly-regulated markets require highly-skilled employees with high levels of cultural capital to meet new challenges: "It is a highly skilled job and there are not many firms doing what we do - pioneering work on liver tissue; essentially, what we are doing on a daily basis is innovative” (Medical Research Firm). It is also important for individuals in such firms to engage in continual learning, as they face a succession of problems that are often unique to their firm; problem solving was often seen as a learning curve whereby knowledge used and gained during the process could be used to solve problems in future.

Across the 40 case study firms, therefore, we propose that cultural capital is a key resource required for successful problem solving. Firms with high levels of internal cultural capital had developed in-house expertise or recruited new employees to enhance existing cultural capital. Such investment had paid off, as firms that did not need to seek knowledge and skills outside the firm were more likely to show high levels of successful problem solving and innovation. However, other firms had experienced difficulties in attracting and retaining skilled staff, forcing them to acquire cultural capital from external sources, principally professional advisers ("We use our bank manager, accountant and solicitor to help with specialist or regulatory issues”: Software Developer), mentors or representatives of the supply chain. The lack of internal expertise was not an insurmountable barrier to problem solving and innovation, but could be overcome by knowing where to access information and by working with others.

The experiences of firms in our study demonstrated that problem solving encourages incremental innovation, which in turn builds individuals' knowledge. This created a positive cycle in both sets of sample firms; for example, farmers could apply new-found knowledge to expand their business activities, whereas a firm engaged in medical research could claim that: 


\section{Using capital theory to explore problem solving and innovation in small firms}

"We are one of only a few UK companies that offer human tissue to the UK Health Service. We are innovative in both our product range and the way we do things”.

Our data imply that, as with social capital, higher levels of cultural capital facilitate increased levels of problem solving. We also contend that cultural capital is used to solve problems, rather than problem-solving activity being responsible for increased levels of cultural capital. Firms able to access and utilise greater levels of cultural capital conducted more effective problem solving than firms that were unable to do so - subject to the 'hierarchy of success' set out below. The most successful firms at problem solving (hence with the greatest potential for innovative activity) were those firms that had in-house expertise through highly skilled staff (such as those engaged in medical research). Firms that relied upon a mixture of internal and external capital were also able to solve problems; such firms had good levels of cultural capital and access to good social networks, although solving problems took longer because of the time taken to connect with the relevant parts of their network. Finally, firms dependent on specialist cultural capital from external sources often took longer still to solve problems and had many ongoing issues that remained unresolved. Delays in this context stemmed from the time taken to access specific expert knowledge from relevant parts of their network, as well as the need to design specialist solutions to problems.

\section{Theme Three: Amplification effect.}

There appears to be a mutually-reinforcing, positive relationship between the two capitals discussed in detail above. Our empirical research revealed that, where individuals in small firms (owners and/or employees) possessed higher levels of social capital, the level of cultural capital tended to be higher, whereas firms with lower social capital had generally lower levels of cultural capital. This link is subtle, but it has important implications.

In particular, we found consistent evidence that firms with higher levels of social capital were better placed to access knowledge from individuals outside the organization, for example: a specialist manufacturer in CS2 had established a valuable network of connections to enhance its specialist cultural capital and, in turn, its success in finding solutions to business problems. By contrast, a software developer had low levels of social capital and the entrepreneur was very conscious of the need to obtain specialist cultural capital from outside sources; this factor dictated his choice of location:

"I have a good mentor from a company in Liverpool; the company is 5 years ahead of ours and he is very knowledgeable. No one in this geographical area would be of help 


\section{Using capital theory to explore problem solving and innovation in small firms}

to us. The reason I located the firm in this incubator was that I was offered a mentoring service”.

In CS1, a farmer's son had worked on farms across the globe and he also had an active network with contemporaries from his university days; he was able to approach individuals who could provide him with unrivalled knowledge of cross-breeding and milk production: "I have worked on different farms, travelled and studied at university, and I have a good network of people I can seek to approach when I am faced with a problem”. By contrast, another farmer attempted to make informed decisions by reading as much as possible on the topic in question, but this individual acknowledged that his personal research proved to be less effective than asking experts or other farmers.

The subtle interaction between social and cultural capital, and the consequent 'amplification effect', implies that firms need a variety of resources in order to solve problems and to innovate. It is critical to note, however, that any resources, whether developed internally or acquired externally, have to address the particular problem at issue. In the absence of internal cultural capital, it is possible to use social capital to access external cultural capital.

Our study places great emphasis on the level of trust associated with networks and social capital; this would imply that strong ties exist where levels of trust are high and weak ties reflect lower degrees of trust. In CS1, for example, a farmer's wife would purposively use her network of farming friends if she required specialist knowledge, whereas another farmer's son gathered multiple sources of information from both trusted and non-trusted sources before making an informed decision about a particular problem.

It was also possible to develop expertise within the organization, provided that organizational structures, systems and routines are in place to encourage the distribution and embedding of knowledge and skills. As Yli-Renko et al. (2001, p599) suggest, this process would include: “creating 'space' for activity that enables problem solving through creating the capacity and structures for knowledge acquisition (via external networks), and the capacity for internal knowledge dissemination and sharing”.

It could be argued from our study that the amplification effect rests solely on whether internal levels of social and cultural capital enable a firm to identify and access external resources (as the farming examples immediately above suggest). However, we propose that the magnitude of the amplification affect increases as the level of social and cultural capital increases, thus leading to a positive reinforcement cycle. The outcomes in terms of problem 


\section{Using capital theory to explore problem solving and innovation in small firms}

solving and innovation thus depend on the people working within the firm and their ability to successfully utilise those resources. For example, firms in CS1 (both construction firms and farms) relied heavily on trusted inner networks and were less likely to access wider networks. Likewise, CS1 firms with higher levels of social capital could also utilise a wider and more diverse range of cultural capitals. In CS2, firms that networked actively to secure specific benefits were also more likely to reap the benefits of higher levels of cultural capital.

\section{Implications and Suggestions for further Research}

There are a number of practitioner implications of this research, stemming from the need to understand the resource capability of not only the individuals working in smaller enterprises but also the enterprise itself. Consultants and practitioners need to consider how small enterprises use resources (social and cultural capital) and appreciate the link between the two capitals that results in the amplification effect. The social and cultural capital for successful innovators is characterised by a range of networks and skills, for example a wide range of networks allows smaller enterprises to access a diverse range of skills; the development of networks specific to the enterprise's industry or specialism is also advantageous - particularly where there is a culture of trust and sharing information. Regional authorities could assist smaller firms by encouraging them to develop small discussion groups whereby problems could be shared. This may be particularly useful for start-up firms or those experiencing high levels of growth and would be a relatively simple way for a small firm to increase access to external social and cultural capital. Small firms could also benefit from developing or accessing networks with their suppliers and customers.

For the academic community, the paper raises some important questions relating to the unique ways in which small firms gain access to and utilise social and cultural capital and, in turn, how these processes affect the ability of both individuals and firms to solve problems successfully and thereby increase their ability to engage in innovative activity.

Even though the overall number of firms studied (40) was relatively small, our findings are based on 52 interviews from organizations operating in different locations and in a number of industries; the data collected cast new light on some critical issues for the small firm community and permit comparative analysis (Yin, 2003).

However, we would make a number of suggestions for further research in this area. Firstly, future studies may wish to focus attention on firms in one sector, in order to gain a deeper understanding of the use of Bourdieu's capitals in a more specific context. Secondly, 


\section{Using capital theory to explore problem solving and innovation in small firms}

our examination of the role of resources could be extended by reference to Bourdieu's notion of field. The field provides a structure (and rules of the game) where actions enable players to gain control over existing resources and to expand the resources at their disposal (Bourdieu, 1986; Flint and Rowlands, 2003). Players’ positions in the field are determined by their present and potential situation in relation to the distribution of power (or capital) amongst players and institutions (groups of players). In playing games, our initial findings on the interlocking nature of Bourdieu's capitals could be explored in more depth, for example: research into innovation in small firms could integrate the influence of the micro and macro environments. Finally, it would also be worthwhile to investigate what happens to an SME that loses a key resource, for example: what are the implications for the firm that loses an individual who possesses high levels of social and cultural capital?

\section{Conclusions}

This study set out to explore problem solving and innovation from a capital theory perspective. Problems encountered by small firms often stem from changes in the external environment, and firms respond in different ways using a mix of resources. In order to solve problems and implement solutions in their daily working lives, individuals need to have access to, and control over, valuable resources; the use of cultural and social capital in this context has rarely been the subject of academic research.

Our study addressed the call of Crossan and Apaydin (2010) for micro-level analysis of innovation theory, and responded to the promptings of researchers who have argued for more studies that exploit the theoretical and empirical base of Bourdieu's work in organizational analysis (Emirbayer and Johnson, 2008; Vaughan, 2008). We contend that the use of Bourdieu's capital theory to explore problem solving and innovation in small firms has the potential to make a major contribution to the literature in this field, and that the findings reported here are the first stage in that process.

The key findings across our sample firms indicate that social capital, especially in the form of networking with internal or external sources, was important in solving problems and in creating an innovative business climate. Cultural capital was also required for successful problem solving, particularly the capacity to access specialist, problem-specific knowledge. Both of these assertions confirm previous work but our contribution lies in the application of Bourdieu's work to problem solving and innovation in the SME context. 


\section{Using capital theory to explore problem solving and innovation in small firms}

Within these broad conclusions, a number of more specific findings also contribute to our understanding of problem solving and innovation, particularly at the micro level. First, firms accessed and utilised both inner and outer capitals, but the utilisation of the latter was more evident in firms located in or near urban areas. Second, where individuals in small firms (whether entrepreneurs, family members or employees) possess higher levels of social capital, the level of cultural capital is generally higher. This amplification effect is important for successful problem solving. This effect led us to propose that firms need a variety of resources specific to the problem at issue (technical knowledge, access to a dedicated network and so on), in order to solve problems and thus to grasp an opportunity to innovate.

Themes One and Two, covering social and cultural capital respectively, confirmed the critical role of networks and knowledge accumulation in problem solving and innovation (as revealed in, for example: Rothwell, 1994; Corti and Storto, 2000; Deakins et al., 2000; Perez and Sanchez, 2002). Furthermore, and critically, the use of Bourdieu's capital theory allowed the authors to explore the interdependence between the different forms of capital in Theme Three (the amplification effect).

Overall, we argue that higher levels of social and cultural capital in small firms lead to greater success in solving problems and implementing solutions which, in turn, leads to increased levels of innovation.

To conclude, problems often originate from changes in the external environment, and firms respond in different ways, using a mix of resources. In order to solve problems and implement solutions, individuals within small firms need to have access to, and control over, valuable resources. This paper explores the role of social and cultural capital in solving problems and implementing appropriate solutions. It contributes to the literature on small firms, resource management and innovation, and addresses the call for work that exploits the theoretical and empirical base of Bourdieu's work to analyse the ways in which organizations evolve, in particular how different forms of capital are utilised in the day-to-day operations of small firms (Emirbayer and Johnson, 2008; Vaughan, 2008). Using Bourdieu’s theory of capital, we have explored further the micro-level analysis of innovation and problem solving in small firms. The results have affirmed the nuanced link between social and cultural capital, and the complex environments in which small firms operate. The impact of amplification increases as the levels of social and cultural capital increase, thus leading to a positive reinforcement cycle. However, the outcomes in terms of problem solving and 
Using capital theory to explore problem solving and innovation in small firms

innovation depend on the people working within the firm and their ability to utilise those resources successfully.

\section{Acknowledgements}

Part of this work was supported by the former East Midlands Development Agency, UK.

\section{References}

Aarstad, J., Haugland, S.A., and Greve, A. (2010), “Performance spillover effects in entrepreneurial networks: Assessing a dyadic theory of social capital”, Entrepreneurship, Theory and Practice, September, pp.1003-1019.

Audretsch, D.B., Lehmann, E.E., and Plummer, L.A. (2009), “Agency and Governance in Strategic Entrepreneurship”, Entrepreneurship, Theory and Practice, January, pp.149166.

Barney, J. (1991). "Firm resources and sustained competitive advantage". Journal of Management, Vol. 17, No. 1, pp. 99-120.

Baron, R., and Markman, G.D. (2005), “Beyond social capital: The role of entrepreneurs' social competence in their financial success”, Journal of Business Venturing, Vol. 18, pp. 41-60.

Bell, J. (1993). Doing Your Research Project: A Guide for First Time Researchers in Education and Social Science, 2nd Edition, Open University Press: Buckingham UK

Bourdieu, P. (1977, translation of original in 1972). Outline of Theory of Practice. translated by Richard Nice. Cambridge University Press: Cambridge.

Bourdieu, P. (1983), The Field of Cultural Production, or The Economic World Reversed. Poetics Vol. 12, pp.1.

Bourdieu, P. (1984), Distinction: A Social Critique of the Judgement of Taste, translated by Richard Nice. Routledge, Kegan Paul, London.

Bourdieu, P. (1986), The Forms of Capital. In Richardson J.G. (ed.) Handbook of Theory and Research for the Sociology of Education. NY: Greenwood Press.

Bourdieu, P. (1990), The Logic of Practice, Stanford University Press, Stanford: CA.

Bourdieu, P. (1991), Language and Symbolic Power, Cambridge Polity Press.

Bourdieu, P. (1998), Practical reason On the Theory of Action, Stanford University Press, Stanford: CA. 


\section{Using capital theory to explore problem solving and innovation in small firms}

Boussouara, M., and Deakins, C. (2000), “Trust and the Acquisition of Knowledge from Non-executive Directors by High Technology Entrepreneurs”, International Journal of Entrepreneurial Behaviour and Research, Vol. 6, No. 4, pp.204-226.

Bruneel, J. Yli-Renko, H., and Clarysse, B. (2010), “Learning from experience and learning from others: how congenital and interorganizational learning substitute for experiential learning in young firm internationalization”, Strategic Entrepreneurship Journal, Vol. 4, No. 2, pp.164-182.

Buijs, J.A. (1987), “Innovation can be taught”, Research Policy, Vol. 16, pp.303-14.

Caley E., Chell, E., Chittenden, F. and Mason, C. (Eds) (1992), Small Enterprise Development Policy and Practice in Action, Paul Chapman Publishing.UK.

Cassell, C., and Symon, G., (Eds.). (1994), Qualitative Methods in Organizational Research A Practical Guide. Sage Publications Ltd, London.

Champion, D., and Wilson, J.M. (2010). “The Impact of Contingency Factors on

Validation of Problem Structuring Methods”, Journal of the Operational Research Society, Vol. 61, No. 1, pp. 1420-1431.

Clarke, E. (2000), The Role of Social Capital in Developing Czech Private Business. Work, Employment and Society, Vol 14, No. 3, pp.439-458.

Cohen, W., and Levinthal, D. (1990), “Absorptive Capacity: A New Perspective on Learning and Innovation”, Administrative Science Quarterly, Vol. 35, pp.128-152.

Coleman, J.S. (1988), “Social Capital in the Creation of Human Capital”, American Journal of Sociology, Vol. 94/Supplement: S95-S120.

Corti, E., and Storto, C. (2000), “Knowledge Creation in Small Manufacturing Firms During Product Innovation: An Empirical Analysis of Cause-effect Relationships Among its Determinants”, Enterprise and Innovation Management Studies, Vol. 1, No. 3, pp.245263.

Crossan M.M., and Apaydin M. (2010), “A Multi-dimensional framework of organizational innovation: A systematic review of the literature”, Journal of Management Studies, Vol. 47, No. 6, pp.1154-1191.

Daniels, K.J., Boocock, J.G., Glover, J.L., Hartley, R., and Holland, J. (2008), “An experience sampling study of learning, affect, and the demands control support model”, Journal of Applied Psychology, Vol. 94, No. 4, pp1003-1017. 


\section{Using capital theory to explore problem solving and innovation in small firms}

Deakins, D., O’Neill, E. and Mileham, P. (2000), “Executive Learning in Entrepreneurial Firms and the Role of External Directors”, Education and Training Vol. 42, No. 4/5, pp.317-325.

De Carolis, D.M, and Saparito, P. (2006), “Social Capital, Cognition, and Entrepreneurial Opportunities: A Theoretical Framework”. Entrepreneurship, Theory and Practice, January, pp.41-56.

De Carolis, D.M., Litzky, B.E., and Eddleston, K.A. (2009), "Why networks enhance the progress of new venture creation: The influence of social capital and cognition”. Entrepreneurship, Theory and Practice, March, pp.527-545.

De Clercq, D., and Voronov. M. (2009), “The Role of Cultural and Symbolic Capital in

Entrepreneurs’ Ability to Meet Expectations about Conformity and Innovation”. Journal of Small Business Management Vol. 47, No. 3, pp.398-420.

Dodgson, M. (1993), “Organizational Learning: A Review of Some Literatures”,

Organization Studies Vol. 14, No.3, pp.375-394.

Eisenhardt, K., and Graebner, M. (2007), “Theory building from cases: Opportunities and challenges”, Academy of Management Journal, Vol. 50, No. 1, pp.25-32.

Emirbayer, M., and Johnson, V. (2008), “Bourdieu and organizational analysis”, Theoretical Sociology, Vol. 37, pp.1 - 44.

European Union (2014) A new SME Definition, Enterprise and Industry Publications - see: http://ec.europa.eu/enterprise/policies/sme/files/sme_definition/sme_user_guide_en.pdf, accessed 2022014.

Field, J. (2003) Social Capital. Routledge: NY

Findlay, P., McKinlay, A., Marks, A., and Thompson, P. (2000), "In search of perfect people: teamwork and team players in the Scottish spirits industry”, Human Relations, Vol. 53, No. 11, pp.1549-077.

Flint J. and Rowlands. R. (2003), "Commodification, Normalisation and Intervention: Cultural, Social and Symbolic Capital in Housing Consumption and Governance”, Journal of Housing and the Built Environment Vol 18, pp.213 - 232.

Freel, M. (2000), “External linkages and product innovation in small manufacturing firms”, Entrepreneurship and Regional Development, Vol. 12, pp.245-266

Freeman, C., and Hagedoorn, J. (1994), “Catching up or falling behind: patterns in international interfirm technology partnering”, World Development, Vol. 22, No. 5, pp.771-80. 
Using capital theory to explore problem solving and innovation in small firms

Furstenberg, F. (2005), “Banking on Families how Families Generate Social Capital”. Journal of Marriage and Family Vol. 67, pp.809-821.

Ghobadian, A., Mole, K., and O’Regan, N. (2003), “New Process Technologies: Barriers to Adoption in Small Firms [1]”, International Journal of Manufacturing Technology and Management Vol. 5, No. 5,6, pp.549.

Gibson, D. (Ed) (1991), Technology Companies and Global Markets. Rowman \& Littlefield, cited in: Conway, S., and Jones, O. (2012), “Entrepreneurial networks and the small business, Chapter 19, pp. 338-361., in Enterprise and Small Business, Cater, S., and Dylan-Jones, D. (Eds): Pearson Education Limited, Harlow, England.

Giroux, I. (2009), "Problem solving in small firms: an interpretive study”, Journal of Small Business and Enterprise Development, Vol. 16, No. 1, pp.167 - 184

Glaser, B.G. (Eds) (1996), Gerund Grounded Theory. The Basic Social Process Dissertation. Sociology Press: Mill Valley, CA.

Grande, J., Madsen, E. L., and Borch. O.J. (2011), “The relationship between resources, entrepreneurial orientation and performance in farm-based ventures”. Entrepreneurship and Regional Development, Vol. 23, No. 3-4, pp.89-111.

Granovetter, M. (1985), “Economic Action and Social Structure: The Problem of Embeddedness”, American Journal of Sociology Vol. 91, No. 3, pp.481-510.

Gray, C. (2002) Entrepreneurship, Resistance to Change and Growth in Small Firms, Journal of Small Business and Enterprise Development 9(1): 61-72.

Huberman, A.M., and M.B. Miles. (2002), The Qualitative Researcher's Companion. Sage Publications, Thousand Oakes, California.

Ireland, R.D., Hitt, M.A., and Simon, D.G. (2003), “A model of strategic entrepreneurship: The construct and its dimensions”. Journal of Management, Vol.29, No.3, pp.963-989. Jenkins, R. 1992. Pierre Bourdieu. Routledge: London

Kalantaridis, C., and Pheby, J. (1999), "Processes of Innovation among manufacturing SMEs: the experience of Bedfordshire”, Entrepreneurship \& Regional Development, Vol.11, pp.57-78.

Kazanjian, R. K. (1988), "Relation of Dominant Problems to Stages of Growth in Techno”, Academy of Management Journal Vol.31, No.2, pp.257-279.

Koschatzky, K. (1998), "Firm Innovation and Region: The Role of Space in Innovation Processes”, International Journal of Innovation Management, Vol.2, No.4, pp.383-408. 


\section{Using capital theory to explore problem solving and innovation in small firms}

Leach, T. and Kenny. B. (2000), “The Role of Professional Development in Simulating Change in Small Growing Businesses”. Continuing Professional Development Vol.3, No.1, pp.7-22.

Levinthal, D.A. (2000), “Organizational capabilities in complex worlds”. In The nature of organizational capabilities G Dosi, R.R.Nelson, S.G. Winter (Eds.). New York: Oxford University Press; pp.363-379.

Liao, S., Fei, W-C., and Liu, C-T., (2008), "Relationships between knowledge inertia, organizational learning and organization innovation”. Technovation, Vol.28, No.4, pp.183-195.

Lichtenstein, B. M. B., and Brush, C. G. (2001), “How Do 'Resource Bundles’ Develop and Change in New Ventures? A Dynamic Model and Longitudinal Exploration”, Entrepreneurship: Theory and Practice Vol.25, No.3, pp.37-59.

Lin, N. (2001), Social Capital: a theory of social structure and action, Cambridge University Press, Cambridge.

Lundvall, B.A. (1992). National Systems of Innovation: Towards a Theory of Innovation and Interactive Learning. London: Pinter

Lundvall, B.A. and Nielsen, P. (2005), “Innovation, organizational learning and job creation”, European Journal of Economic and Social Systems, Vol.18, No.1, pp.79-97.

McMullen, J.S, and Shepherd, D.A. (2006), "Entrepreneurial action and the role of uncertainty in the theory of the entrepreneur”. Academy of Management Review, Vol.31, No.1, pp.132-152.

Mohannak, K. (2007), "Innovation networks and capability building in the Australian hightechnology SMEs”, European Journal of Innovation Management, Vol.10, No.2, pp.236251.

Motwani, J., Dandridge, T., Jiang, J., and Soderquist, K. (1999), “Managing innovation in French small and medium-sized enterprises”, Journal of Small Business Management, Vol.37, No.2, pp.106-16.

Patton, D., and Marlow, S. (2002), “The Determinants of Management Training within Smaller Firms in the UK. What Role Does Strategy Play?” Journal of Small Business and Enterprise Development Vol.9, No.3, pp.260-270.

Pavia, T. M. (1991), “The Early Stages of New Product Development in Entrepreneurial High-Tech Firms”. The Journal of Product Innovation Management Vol.8, No.1, pp.18. 
Perez, M. and Sanchez. A. (2002), "Lean Production and Technology Networks in the Spanish Automotive Supplier Industry”. Management International Review Vol.43, No.3, pp.261-277.

Portes, A. (2000). “Social Capital: Its Origins and Applications in Modern Sociology”, Annual Review of Sociology, Vol. 24, pp. 1-24.

Putnam, R.D. (1993), Making Democracy Work: Civic Traditions in Modern Italy. Princeton University Press, Princeton, US.

Ray, G., Barney, J.B., and Muhanna, W.A. (2003), “Capabilities, Business Processes and Competitive Advantage: Choosing the Dependent Variable in Empirical Tests of the Resource-Based View”. Strategic Management Journal, Vol.25, No.1, pp.23-37.

Romero, I. (2011), “Analysing the composition of the SME sector in high- and low-income regions: Some research hypotheses”, Entrepreneurship \& Regional Development, Vol.23, No.7-8, pp.637-660.

Rothwell, R. (1994), "Towards the fifth-generation innovation process", International Marketing Review, Vol.11,No.1, pp.7-31.

Schuller, T., Baron, S., and Field, J. (2000), "Social Capital: A Review and Critique”, Chapter 1, pp.1-38., in: Social Capital, Critical Perspectives, (Eds) Baron, S., Field, J., and Schuller, T. Oxford University Press: England.

Schulman, M.D. and Anderson. C.D. (1999), "The Dark Side of the Force: A Case Study of Restructuring and Social Capital”. Rural Sociology Vol.64,No.3, pp.351-372.

Scott, S.G., and Bruce, R.A. (1994), "Determinants of Innovative Behavior: A Path Model of Individual Innovation in the Workplace”, The Academy of Management Journal, Vol. 37, No. 3 (Jun.), pp. 580-607

Storey, D.J., and Greene, F.J. (2010), Small Business and Entrepreneurship. Pearson Education Limited, Harlow, England.

Tolstoy, D., and Agndal, H., (2010), "Network resource combinations in the international venturing of small biotech firms”, Technovation, Vol.30, No.1, pp.24-36

Vaughan, D. (2008), "Bourdieu and organizations: the empirical challenge”, Theoretical Sociology, Vol.37, pp.65-81.

Vissa, B. and Bhagavatula, S. (2012), “The causes and consequences of Churn in Entrepreneurs’ personal networks”, Strategic Entrepreneurship Journal, Vol.6,No.3, pp.273-289. 


\section{Using capital theory to explore problem solving and innovation in small firms}

Von Hippel, E. (1994), “Sticky information and the locus of Problem Solving: Implications for innovation”, Management Science, Vol.40, No.4, pp.429-439.

Vossen, R (1999), “Relative strengths and weaknesses of small firms in innovation”, International Small Business Journal, Vol.16, pp.88-94.

Watts T., Swann G. M. P., and N. Pandit (1998), “Virtual Reality and Innovation Potential”, Business Strategy Review, Vol.9, No.3, pp.45-54.

Wernerfelt, B. (1984). “A Resource Based View of the Firm” Strategic Management Journal, Vol. 5, pp. 171-180.

Wright, M., Liu, X., Buck, T., and Filatotchev, I. (2008), "Returnee entrepreneurs, science park location choice and performance: An analysis of high technology SMEs in China”, Entrepreneurship, Theory \& Practice, Vol.32, pp.131-155.

Yin, R. (2003), Case Study Research Designs and Methods. $3^{\text {rd }}$ Edition, Applied Social Research Methods Series Volume 5, Sage Publications, London.

Yli-Renko, H., Autio, E. and Sapienza, H.E. (2001), “Social capital, knowledge acquisition, and knowledge exploitation in young technology-based firms”. Strategic Management Journal Vol.22, pp.587-613.

Zaltman,G, Duncan R. and Holbek, J. (1973), Innovation and Organizations. New York: John Wiley and Sons. 